\begin{tabular}{|r|}
\hline ANGIES \\
NEW PERSPECTIUE5 \\
ANELOPHONE WTRLL \\
\hline
\end{tabular}

\title{
Angles
}

New Perspectives on the Anglophone World

$6 \mid 2018$

Experimental Art

\section{F. H. Bradley's Neoplatonic Turn in Ethical Studies (1876)}

Jean-Paul Rosaye

\section{Q OpenEdition \\ 1 Journals}

\section{Electronic version}

URL: https://journals.openedition.org/angles/1077

DOI: $10.4000 /$ angles. 1077

ISSN: 2274-2042

\section{Publisher}

Société des Anglicistes de l'Enseignement Supérieur

\section{Electronic reference}

Jean-Paul Rosaye, "F. H. Bradley's Neoplatonic Turn in Ethical Studies (1876)", Angles [Online], 6 | 2018, Online since 01 April 2018, connection on 06 June 2022. URL: http://journals.openedition.org/angles/ 1077 ; DOI: https://doi.org/10.4000/angles. 1077

This text was automatically generated on 6 June 2022.

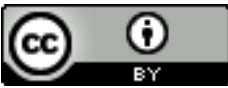

Angles est mise à disposition selon les termes de la Licence Creative Commons Attribution 4.0 International. 


\title{
F. H. Bradley's Neoplatonic Turn in Ethical Studies (1876)
}

\author{
Jean-Paul Rosaye
}

1 According to a persistent interpretation, Francis Herbert Bradley was a major representative of a neo-Hegelian trend that spread in Britain in the late-Victorian period and consolidated into a British Idealist movement. It also insists that this philosophical experiment was short-lived, as it was overwhelmed at the beginning of the $20^{\text {th }}$ century by a philosophical revolution initiated by Bertrand Russell and George Edward Moore. However, this interpretation has been wholly reconsidered since the 1980s following the formidable reassessment not only of Bradley's metaphysics but also of the impact of the whole movement in British philosophy and politics. ${ }^{1}$ Russell's importance as a philosopher has not been undermined in this revision, but it is now accepted that Bradley's philosophy and the Idealist movement were not a mere transition filling the gap between the old empiricist school of the mid-19 ${ }^{\text {th }}$ century and the new analytical philosophy of the early $20^{\text {th }}$ century (Rosaye 2012a). If anything, British Idealism is now viewed as a complex and cogent philosophical stream that can neither be disproved, nor neglected and disposed of easily.

2 One of the major attacks led by Russell against idealism was the accusation of its subservience to Hegelianism, whose main representative in England was Bradley. Russell aimed at what he perceived as Bradley's Hegelian metaphysical shortcomings to perform his own revolution, but like all successful revolutions it was also linked to other factors. On closer scrutiny, Russell's new philosophical tools were also promoted by the scientific revolution, as they were simply better adapted to the new logical and physical models contradicting the old Newtonian world-system. All the philosophies which had heavily invested in epistemology and ontology, while following the methods that had befitted the Newtonian world of science, had become either outmoded or useless.

3 Yet, the claim that Bradley's so-called Hegelian philosophy was the heart of the matter, and the idea that Russell's thrusts explain the demise of Idealism and the philosophical upheaval in the last century, are nevertheless elements worth exploring as they seem 
neither totally right nor totally wrong. The dilemma runs as follows: after showing great interest in Hegel's philosophy, Bradley openly rejected Hegelianism and denied there was anything like a Hegelian school in England; Bradley's repudiation of Hegelianism was criticised by the British Idealists who still regarded Hegel's metaphysics as the main model to follow; a split in the Idealist movement occurred between monists and personal idealists, prompted by a refusal of some aspects of Hegel's system and of Bradley's monism, which by that time had diverged from Hegelianism; lastly, Bradley considered that his own metaphysics ended with "something not very different, something perhaps more certainly the essential message of Hegel" (AR 552).

4 Bradley's interpretation of Hegel is obviously the clue to this dilemma, and it has to be explained to rectify the claim of his debt to Hegel. Moreover, as Russell's misunderstanding or perhaps fraudulent interpretation of Bradley was effective (Wander 1994: chap. 4; Candlish 2007), we can conjecture that it touched upon the difficult importation of Hegelianism in Britain, where an old idealist tradition already existed and had re-emerged at the beginning of the $19^{\text {th }}$ century.

Contrasting with the introduction of Kant's philosophy in Britain, Hegel's philosophy had always been treated with caution and had met with frequent disapproval. Finally, the compatibilities between Hegelianism and the existing idealist tradition in England engaged the whole Idealist movement into such scholastic quandaries that an Occamian razor-like intervention was needed.

6 This essay aims to show how Bradley, after using Hegel's conceptual power and vigour to dig strenuously into the perplexities of his age, turned to Neoplatonism and conceived an original metaphysical position which forced other idealists to question their own. Eventually, although it provided considerable philosophical speculation, shaking English philosophy out of its former simplistic complacency, the British Idealist movement did not get over its divisions, sounded out of place. It was finally taken over by the congenial empiricist and common sense traditions, better adapted to the new emerging scientific world-system.

71865 was a key date in the history of British philosophy. While Bradley entered University College, Oxford, to study philosophy as an undergraduate that year, two important books were published: John Stuart Mill's An Examination of Sir William Hamilton's Philosophy, and John Hutchison Stirling's The Secret of Hegel. These books were epoch-making as they symbolically marked the end of the philosophical domination of the empiricist and common sense traditions in Britain and the birth of the British Idealist movement. The famous controversy regarding the relativity of knowledge ${ }^{2}$ started by Mill (1873) to oppose Hamilton's philosophy and its major exponents has to be seen in the wider context of the main issues of the Victorian Age, set in a tension between the traditional make-up of 'old and merry England' and the modernising forces of industrial society. What was needed at that time was a theoretical foundation adapting the traditional settings of a Christian society to the new advance made by scientific knowledge and the transformations of society. In other words, it had become crucial to temper the materialist drive supported by the naturalists and the positivists, as well as to remedy the 'Victorian crisis of faith' of the 1850 s and $1860 \mathrm{~s}^{3}$. The solution offered by Kant, showing the limits of the understanding to fathom the realm of the 'thing in itself' and leaving reason to the practical field of our actions and judgments was turned by Hamilton, Mansel and Spencer into the vague theory of the 
'Unknowable' where faith and religion were mixed in a rather confused form of mysticism. This solution was not sufficient, and the naturalist-scientist devotees, though they were theoretically committed to confuting the relativity of knowledge, finally put up with it as it ruled out any interest in the absolute and left science with the task of building up a consistent knowledge of the world. But the 'relativity of knowledge' controversy only reached stalemate and left the two camps with the inability to produce any useful and reliable philosophical agreement (Rosaye 2012b).

For quite some time, a myth was entertained that Stirling's book, The Secret of Hegel, provided in 1865 the answer to the 'Victorian crisis of faith', making Hegel the champion of Christianity, and setting up the neo-Hegelian school which responded to the metaphysical issue in sketching the much-needed doctrine of the Absolute. But there are good reasons to believe this was indeed a myth. Conveniently, it provides a date for the beginning of the British Idealist movement, but it is misleading as it conveys a simplistic picture of the Idealist achievement in the $19^{\text {th }}$ century. In addition, despite the enormous success of his book, Stirling was not taken seriously in British universities, which he never joined as a fellow; and it was also mockingly remarked at the time that he had kept Hegel's secret very well. Other elements must be taken into account.

9 Since Coleridge and Carlyle, and perhaps starting with the Romantic criticism of utilitarianism, laissez-faire economics and industrial society as a whole, idealism had materialised as one possible answer to the alienating venture of modernity. The tradition of Platonic idealism in England was reinvigorated by Coleridge and Carlyle to contradict what T. H. Green called the 'popular philosophy' stemming from the spirit of the Aufklärung (Green 1888). Their intellectual fight against abstract egalitarianism, the Jacobin passion, and Napoleonic imperialism was in tune with the conservatism of Burke but also with Fichtean nationalism and the idealist revolution in Germany that Kant had started in an attempt to restore the notion of transcendence. These 'literary philosophers' were only the first phase of growth of idealism in the $19^{\text {th }}$ century, but their enterprise was extended and systematised by philosophers who, while they resorted to a strategic use of German Idealist philosophy, also fostered a revival of Greek letters, going back as it were to the basics of the philosophical endeavour.

Alongside Stirling's passion for Hegel, Benjamin Jowett had a decisive influence in introducing Hegel's philosophy in the curriculum at Balliol College in the 1860s, asking Edward Caird and T.H. Green to use it as a model to counter the philosophies of Spencer, Mill and Alexander Bain. But Jowett embodied the ambiguities of Hegelianism in Britain as he gradually refrained from the strategic use of Hegel and decided to return to Plato and offer a translation of his dialogues to contribute to the Philhellenic ideal in Britain. The ambiguity of this derivation, either following Hegel, or imparting new vitality to Platonic studies, was reconciled by Green. ${ }^{4} \mathrm{He}$ infused a real interest for philosophical speculation to his students (Nettelship 91-7), and he gathered the problems of his age in an adroit parallel with the time of Protagoras, equating the task of Plato and Aristotle against the Sophists with the fight led by Kant and Hegel against the materialism and agnosticism of the modern age (Green 1888). In the wake of Green's teaching at Balliol, his students also aimed at a theoretical refoundation of philosophy and considered that Mill's philosophy was much below what was needed. As William Wallace wrote, "[Mill's] conception, although a desirable one, falls short of the work which Hegel assigns to philosophy" (Wallace xxii). 
11 It is possible to distinguish three main perspectives in the idealist movement which moved in the direction indicated by Green: the historical question of progress and evolution, the care for politics and ethics, and a philosophical reinterpretation of religion. The first two followed the Hegelian theme of the progress of reason in history. Hegel's conceptual precision and systematicity was helpful, even if it required arduous efforts and time for Green and his students to match their model. The third perspective, the religious question, was much more delicate. Even if some scholars have intimated that the German Idealist philosophers finalised the ideal of the Reformation (Jaeger 324, qtd by Gallet 130) and that Hegel came to crown their intellectual monument, the complexity of the religious question in England prevented from the outset direct use of Hegelian schemes. This is the general intellectual context in which Bradley emerged as the most central and enigmatic representative of the whole British Idealist movement. As he listened to Green's lectures and had chosen him as his tutor to supervise his first essays, he could neither escape the rising tide of Hegelianism nor the strong bias in favour of classical studies in Oxford. Nor could he ignore the philosophical and religious conflicts of his day.

Bradley became a fellow of Merton College in 1870 and in the following four years he directly worked on some key debates of his time, such as the question of miracles, the critical method, and the relativity of knowledge. We can trace the evolution of his thought concerning Hegel's philosophy in his pamphlet on critical history which discusses these issues, The Presuppositions of Critical History, published in 1874, two letters sent to his brother in February 1873, and a manuscript entitled 'The Relativity of Knowledge' written in 1873-74, that is to say, just a few years before the publication of his first important work, Ethical Studies (1876) - made him famous on the philosophical scene. It is in this period that Bradley first formulated the key ideas that he developed afterwards in his epistemological and metaphysical works.

13 His pamphlet on critical history, and more specifically his note E, in the appendix, which is the real conclusion of the book, was centred on the idea of the finiteness of man: "Everything, we have said, depends on personal experience" (PCH 59). The main problem comes from the mediation with the universe, which Bradley considered as a system, an organism, not unrelated to man's thought and feeling:

The universe seems to be one system; it is an organism (it would appear) and more.

It bears the character of the self, the personality to which it is relative, and without

which for us it is as good as nothing ( $\mathrm{PCH} \mathrm{65).}$

14 How is it possible to characterise the mediation between the finiteness of man and the infinite, to reach the truth of any singular historical moment, as well as the reality of the universe? It is of course an important Hegelian theme. But the main problem comes from the fact that Hegel presupposed the perfect mediation of Reason, introducing the idea that God is thought, and that man could also have access to absolute knowledge. This went beyond the Kantian presupposition of man's fallibility and openly challenged the usual conceptions of the relativity of knowledge of the time.

In a letter to his brother Andrew, Bradley exposed Hegel's solution, encapsulated in the famous phrase from the preface of Principles of the Philosophy of Right, "what is rational is real, and what is real is rational", and he did it with some reservations on the meaning of 'rational':

All I was talking about was the theoretical question. I am not competent to say whether Hegel has answered it or not: or whether the question has any sense! The 
question is simply 'Can you account for nonsense?' \& perhaps that is nonsense. Can you from thought generate the world? of course you cannot because you are finite. But if God is thought, does that account for the existence of such a world as ours? Of course not in detail, but can we see far enough to say that God or the thought wh. makes the world a system is the creative prius of the matter of sense, so that nothing is lost but that the sensuous world is (as a whole) beautiful \& rational \& that the rational isn't the dry bones of it merely (Corresp. 4). sense is carefully studied with the help of Hegel's philosophy, that is with the idea that ontology is the solution to the deadlock produced by the conflict between the schools of Mill and of Hamilton, Bradley did not develop what he called "The true doctrine", "the Absolute" as the "reconciled contradiction", and he only sketched the outline of a system on the status of knowledge and on the Absolute as thought. It might have been too early for Bradley, who was just starting his career as a philosopher. But given the fact that by 1883, in his book The Principles of Logic, Bradley was no longer prepared to accept Hegel's main principle, as he made clear in his conclusion (PL Book III, Part II, Chap. IV, §16: 591), it seems evident that his reservations prevented him from following Hegel blindly and produce the system British Idealists were looking for. and distanced himself from the possibility of a perfect mediation by reason alone, through the patient conceptual approach leading to absolute knowledge. Although generally interpreted as his most Hegelian book, mainly because three consecutive essays were written in the shape of a perfect dialectical demonstration and leading to a final statement that echoed the Hegelian Sittlichkeit, where the objective spirit finally reaches maturity, this book is also where Bradley finally turned to a Neoplatonic approach of morality and religion which he would uphold in his later metaphysical works. In his unfinished article on 'Relations', written shortly before his death in 1924, Bradley had fused elements coming from Plotinus' analogy of the "flight of the alone to the alone" as well as from the common Hegelian theme of "unity in diversity":

Nothing in the end is real but the individual; and the individual is unique and (at least in my opinion) there is in the end but one individual which is real and true. And it is individuality that everywhere we seek, and with this alone can be satisfied more or less perfectly in so far as its realisation is more or less complete. And individuality means the union of sameness and diversity, the presence in all of the One and of the One in everything (Essays 'Relations' 663).

Using the Hegelian dialectic and Hegelian themes such as Sittlichkeit does not necessarily mean one is a Hegelian. Actually, one has to accept the whole system to make such a claim. Bradley used dialectics to explain a progression of doctrines (hedonism in Essay 3, the Kantian categorical imperative in Essay 4 and the Hegelian theory of the State in Essay 5) more than he accepted the genuine Hegelian movement of the real towards the Absolute. Whereas Hegel presented philosophy as the final stage of the absolute spirit, Bradley refused this statement, considering instead that religion was the end. In other words, religion is not the result of any internal and dialectical necessity but its cessation, an abandon of the self in the Absolute. This means that the conflict of doctrines and the finiteness of man are only solved in the totality of the Absolute in a non-discursive decision.

Personal experience is presented as the final answer to morality at the very end of Ethical Studies, thus putting an end to the claims of a hedonistic conception of life but also the duties and the actions commanded by society through moral life: 
Here we are landed at last, the process is at an end, though the best activity here first begins. Here our morality is consummated in oneness with God, and everywhere we find that 'immortal love', which builds itself forever on contradiction, but in which the contradiction is eternally resolved (ES 342). explicit Neoplatonism did not come unprepared at the end of Ethical Studies, it was also progressively, and implicitly displayed in Essay 6 ('Ideal Morality') and in Essay 7 ('Selfishness and Self-sacrifice'), before its culmination in the 'Concluding Remarks'. In Essay 7, Bradley produced a series of elements betraying a strong Neoplatonic bent: his genetic theory of morality describing the movement from childhood to adulthood as a progressive elevation from selfishness to self-sacrifice is cast in the cosmic plan of a conflict between two opposing principles, the 'bad self' and the 'good self', more than in a dialectical movement (ES 277); evil has no ontological consistency (ES 279), and the 'worst self' is only selfishness; there is no call for grace, the good is a natural desire and there is pleasure and harmony in it (ES 292).

21

These Neoplatonic themes were not only adjusted to challenge the Hegelian system, nor were they only further developed in the 'Concluding Remarks' of Ethical Studies to counter the Evangelical claims of his time. ${ }^{5}$ They became the foundation of a philosophy of the Absolute that he exposed in his metaphysical work, to the dismay of some British Hegelians. Bosanquet criticized Bradley's departure from Hegel as it undermined the unity of the Hegelian group (Bosanquet 1885: v-vii), and he was closely followed by other Idealists.

Six years before Bradley's first edition of Appearance and Reality, Andrew Seth (PringlePattison in 1898) had already started to shun Hegel's philosophy in his book Hegelianism and Personality (1887). In the conclusion, Seth attacked Hegel who was thought to have undermined the case for the autonomy of the self with his idea of the identification of divine and human consciousness in the realization of Spirit. With Hegel, personal identity was evaded in the structures of the family, the community (Sittlichkeit) and the Absolute. But with Bradley's theory of self, the problem was even worse, as Andrew Seth argued after receiving Appearance and Reality. He more systematically attacked his doctrine of the Absolute later, in an article entitled 'A New Theory of the Absolute' (1894). Criticism switched then from Hegel's to Bradley's monism.

23 As remarked before, Bradley forced the other British Idealists to question their own position regarding Hegel as well as their interpretation of the Absolute. If all were ready to agree with the transcendence implied by the notion of Absolute, few were prepared to welcome the immanence it also contained.

24 It is likely that Bradley escaped the Hegelian conceptual endeavour to reach absolute knowledge in returning to a more insular idealist tradition, in integrating a discourse on the Absolute which had demonstrated some potency. This interpretation was suggested by William Ralph Inge in his 1917-18 Gifford Lectures on the Philosophy of Plotinus, where he remarked that Bradley was a valuable guide to understanding Plotinus (Inge 39-40, 104n1), or in his 1925 Hulsean Lectures published in 1926 as The Platonic Tradition in English Religious Thought where he explicitly linked Bradley's philosophy to the mystical tradition of Christian mysticism.

25 At the end of Appearance and Reality, Bradley rephrased Hegel's principle of the rationality of reality as 'Reality is spiritual' (AR 552). And his postulate that this was Hegel's real secret, not only bears testimony to the role Neoplatonism played in 
German Idealism as well as in the gestation of Hegel's thought, his philosophy also indicates that idealism was a central problem in England.

Ralph Cudworth, one of the Cambridge Platonists of the $17^{\text {th }}$ century, had already been very suspicious of a form of Platonism putting the One, or the Absolute, above everything, refusing the idea of a personal God and confusing Him with nature. And he accused it of pantheism if not atheism. The same accusation was pronounced against Hegel's philosophy, and so did the Personal Idealists of the late $19^{\text {th }}$ century with Bradley's monism. Perhaps they were not off the mark, as Bradley had explicitly written that the lesson Darwinism had imparted to modern society was that "it may force on us in some points a correction of our moral views, and a return to a nonChristian and perhaps a Hellenic ideal” (Bradley 'Some Remarks on Punishment,' April 1894, Essays: 149).

It is therefore hardly surprising that Bertrand Russell capitalised on the rift in British Idealism at the beginning of the $20^{\text {th }}$ century. He himself had been an idealist, and a Hegelian before rejecting it all (Russell 48). Nevertheless, questions remain. It is now well-established that Russell misunderstood Bradley, if he did not force on him metaphysical positions Bradley had never upheld to serve the promotion of his own philosophy (Candlish 2007). Idealism, after all, was too quickly neglected in a century all too ready to abandon metaphysics to suit the brand new theories on universal relativity.

\section{BIBLIOGRAPHY}

Bradley, Francis Herbert. The Presuppositions of Critical History and Aphorisms. Bristol: Thoemmes Press, 1993. Hereafter PCH.

Bradley, Francis Herbert. Ethical Studies. Oxford: The Clarendon Press, 1962 ( $2^{\text {nd }}$ ed. Rev. and corrected 1927, intr. Richard Wollheim). Hereafter ES.

Bradley, Francis Herbert. Principles of Logic. Oxford: Oxford UP, 1928 ( $2^{\text {nd }}$ corrected ed.). Hereafter PL.

Bradley, Francis Herbert. Appearance and Reality: A Metaphysical Essay. London: Swan Sonnenschein \& Co., 1902 (2nd ed.]). Hereafter AR.

Bradley, Francis Herbert. The Collected Works of F. H. Bradley, Vol. 4: Selected Correspondence (June 1872-December 1904). Carol A. Keene, ed. Bristol: Thoemmes Press, 1999. Hereafter Corresp.

Bradley, Francis Herbert. Collected Essays. Oxford: The Clarendon Press, 1935. Hereafter Essays. Bosanquet, Bernard. Knowledge and Reality: A Criticism of M. F. H. Bradley's 'Principles of Logics'. London: Kegan Paul, Trench and Co., 1885.

Boucher, David and Vincent, Andrew. British Idealism: A Guide for the Perplexed. London \& New York: Continuum, 2012. 
Candlish, Stewart. The Russell/Bradley Dispute and its Significance for Twentieth-Century Philosophy. New York: Palgrave Macmillan, 2007.

D’Haussy, Christiane. “1850-1880 : Essor religieux dans une société prospère”. In Hugh McLeod, Stewart Mews, Christiane D’Haussy, eds. Histoire religieuse de la Grande-Bretagne. Paris: Cerf, 1997. 83-116.

Gallet, René. Romantisme et Postromantisme de Coleridge à Hardy: Nature et surnature. Paris: L'Harmattan, 1996.

Green, Thomas Hill. "Popular Philosophy and its relation to Life" (1868). In Works of Thomas Hill Green. Vol. 3: Miscellanies and Memoir. R. L. Nettelship, ed. London: Longmans, Green and Co, 1888: 92-125.

Inge, William Ralph. The Philosophy of Plotinus (The Gifford Lectures at St Andrews, 1917-1918). Vol. 2. London: Longmans Green and Co, 1918.

Jaeger, Hasso. 'La mystique protestante et anglicane.' In La mystique et les mystiques. André Ravier, ed. Paris: Desclée de Brouwer, 1965. 257-380.

Mackenzie, John Stuart. “The Hegelian Point of View”. Mind, NS XI, 1902: 54-71.

Mander, William. British Idealism: A History. Oxford: Oxford UP, 2011.

Mander, William. An Introduction to Bradley's Metaphysics. Oxford: The Clarendon Press, 1994.

Manser, Anthony and Stock, Guy. The Philosophy of F. H. Bradley. Oxford: The Clarendon Press, 1984.

Mill, John Stuart. An Examination of Sir William Hamilton's Philosophy, and of the Principal Philosophical Questions Discussed in his Writings (1865). London: Longmans, Green, Reader and Dyer, 1873 (3 ${ }^{\text {rd }}$ ed.).

Nettelship, Richard Lewis. A Memoir of Thomas Hill Green. London: Longmans, Green and Co, 1906. Rosaye, Jean Paul. F. H. Bradley et l'idéalisme britannique : Les années de formation (1865-1876). Arras: Arras PU, 2012a.

Rosaye, Jean Paul. “'The Relativity of Knowledge': Retour sur une querelle philosophique au milieu de la période victorienne (1865).” In Crise et culture. Martine Piquet, ed. Université de Paris-Dauphine: Cahiers du Ciclas (15) 2012b: 1-10.

Rosaye, Jean Paul. "F. H. Bradley entre orthodoxie et hérésie : le sens des 'Concluding Remarks' de Ethical Studies." Revue française de civilisation britannique. Yannick Deschamps and Suzy Halimi, eds. 18 (1) 2013: 171-181. DOI : $\underline{10.4000 / \mathrm{rfcb} .3652}$

Russell, Bertrand. My Philosophical Development. London: Allen \& Unwin, 1959.

Stirling, John Hutchison. The Secret of Hegel. London: Longman, Roberts \& Green, 1865.

\section{NOTES}

1. Since the publication of The Philosophy of F. H. Bradley by Anthony Manser and Guy Stock (1984) for the centenary of the publication of Bradley's Principles of Logic, there has been a continuous and increasingly strong reassessment of Bradley's philosophy, and of British Idealism more generally. More recently, William Mander's quasi-encyclopedic British Idealism : A History (2011), and David Boucher and Andrew Vincent's highly informative book British Idealism : A Guide for the Perplexed (2012), have suggested that the study of the British Idealists (and of Bradley among 
them) is not only firmly entrenched in philosophical research now, but also that it still provides very innovative insight on British philosophy and British social and political thought from the middle of the $19^{\text {th }}$ century to the $21^{\text {st }}$ century.

2. For a detailed account of this controversy, see Rosaye (2012).

3. The reference to a 'crisis of faith' is mainly, but not totally, due to Charles Darwin's publication of Origins of Species in 1859. See d'Haussy's enlightening article on this question (d'Haussy 1997).

4. This point of view was maintained until the $20^{\text {th }}$ century, as evidenced by Mackenzie (1902: 62).

5. For a study of Bradley's alternation between orthodox and heretic explanations of the Christian doctrine, see Rosaye (2013).

\section{ABSTRACTS}

F. H. Bradley is usually referred to as one of the British neo-Hegelians of the late Victorian period. But the intersection of Hegelian thought with British philosophy at that time was not synonymous with total subservience to Hegel's metaphysics, and Bradley's philosophical development offers an appropriate perspective to assess the importance of this case. The Hegelian influence on the British monists of the late $19^{\text {th }}$ century (Edward Caird, Henry Jones, Bernard Bosanquet, Francis Herbert Bradley) is a well-known fact which has been increasingly studied since the 1980s. But attention to the Platonic tinge in the English form of Idealism has generally been neglected. Bertrand Russell, who acted as the main opponent to Idealism in England at the beginning of the $20^{\text {th }}$ century, had capitalised in particular on a bifurcation in the Idealist movement, due to some misunderstanding over the Hegelian influence. In fact, the source of this rift can be traced back to Bradley's Neoplatonic turn in his Ethical Studies (1876). In this book, Bradley meticulously designed a gradual transformation of his former Hegelian positions towards Neoplatonic intimations of the reflexive motion of the self towards consciousness and complete realization. Bradley's turn from pure Hegelianism to aspects of the Platonic tradition had important consequences in the subsequent history of the British Idealist movement up to the rise of analytical philosophy in the $20^{\text {th }}$ century.

F.H. Bradley est habituellement considéré comme un néo-hégélien anglais de la période Victorienne tardive. Mais le rapport que la philosophie britannique de cette époque a entretenu avec la pensée hégélienne n'implique pas une soumission indéfectible, comme en témoigne l'évolution philosophique de Bradley. L'influence de Hegel sur les monistes britanniques de la fin du dix-neuvième siècle est un fait connu et étudié avec une belle constance depuis les années 1980, alors que les traces de platonisme dans la forme anglaise de l'idéalisme ont généralement été occultées. Bertrand Russell, le célèbre pourfendeur de l'idéalisme au début du vingtième siècle, s'était appuyé dans ses démonstrations sur une bifurcation intellectuelle au sein des idéalistes, laquelle était due à un certain malentendu au sujet de l'influence hégélienne. Or, la source de ce malentendu est déjà observable avec le tournant platonicien effectué par Bradley dans ses Etudes éthiques de 1876. C'est dans ce traité que Bradley a commencé d'infléchir ses positions sur l'idée de soi, initialement hégéliennes, en direction de conceptions néoplatoniciennes. Le détournement de Bradley d'un pur hégélianisme a eu des conséquences importantes dans l'histoire du développement philosophique des idéalistes, jusqu'à l'essor de la tradition analytique au vingtième siècle. 


\section{INDEX}

Keywords: Bradley F. H., Russell Bertrand, British Idealism, Hegelianism, Platonic tradition Mots-clés: Bradley F. H., Russell Bertrand, idéalisme britannique, hégélianisme, tradition platonicienne

\section{AUTHOR \\ JEAN-PAUL ROSAYE}

Jean-Paul Rosaye is Full Professor at the Artois University in France. He is the author of more than sixty articles and conferences, mainly on the history of ideas in a European context, and also of a few books centered on the idealist ascendancy from the late Victorian period to the beginning of the $20^{\text {th }}$ century : T. S. Eliot poète-philosophe: Essai de typologie génétique, [2000]; Autour de l'idéalisme britannique: recherches et réflexions méthodologiques sur l'histoire des idées en GrandeBretagne, [2010] ; F. H. Bradley et l'idéalisme britannique: les années de formation (1865-1876), [2012]. He is vice-director of the humanities research centre "Textes et Cultures" (EA 4028) of the Artois University, and director of a team of researchers working on "Civilization and Transcultural Studies". He is currently working on a translation of F. H. Bradley's famous metaphysical treatise Appearance and Reality as well as on a study of Bradley's metaphysics. Contact:

jpaul.rosaye[at]gmail.com 